\title{
1MDB: The Auditor General Office's Questions
}

\author{
Azham Md. Ali \\ Department of Accounting and Finance, Faculty of Management and Economics \\ Universiti Pendidikan Sultan Idris, 35900 Tanjong Malim Perak Malaysia
}

Tel: 015 48117771: Fax: 01548117295

E-mail: azham@fpe.upsi.edu.my

Received: January 02, 2016 Accepted: February 03, 2016 Published: February 21, 2016

doi:10.5296/jpag.v6i1.9056 URL: http://dx.doi.org/10.5296/jpag.v6i1.9056

\begin{abstract}
Following the prime minister's instruction on March 4, 2015, the Auditor-General Office (AGO) began its audit 1Malaysia Development Berhad (1MDB) on March 10, 2015. But there are some very important questions left unanswered with the conduct of the audit including: What are the objectives of the audit by the auditor-general? Why the prime minister declaring no wrongdoing at the $1 \mathrm{MDB}$ while at the same time wanting AGO audit? Why the failure to specify the necessary such as the probe's terms of reference and timeframe? And last but certainly not the least is: Should the auditor-general be the one to audit the IMDB?
\end{abstract}

Keywords: Auditor General Office, 1MDB, probe, questions 


\section{Introduction}

The Auditor-General Office (AGO) began its audit to verify 1MDB's accounts on March 10, 2015 (FMT Reporters, 2015a). This came about following the prime minister's instruction on March 4, 2015 to the Auditor-General to audit 1MDB. It is notable that the day before the Democratic Action Party (DAP) parliamentarian Tony Pua had lodged a police report about 1MDB's dealings with PetroSaudi (Aw, 2015). It is also notable that the instruction for auditing came after Parliament's Public Accounts Committee (PAC), which is fully bipartisan and reflects Parliament's composition, had already said during the week before that it wanted the national auditor to carry out an audit of transactions in 1MDB before it calls up the company (Ng, 2015a).

It appears that none of these would have happened if not for a series of reports (since mid February 2015) by the United Kingdom-based whistleblower website Sarawak Report which alleged that Malaysian businessman Low Taek Jho or Jho Low had orchestrated the 2009 joint venture between 1MDB and Petro Saudi International to siphon off US\$700 million (RM2.5 billion) from the strategic investor (Ng, 2015a). Needless to say, the Sarawak Report's exposés had piled pressure on prime minister Datuk Seri Najib Razak and prompted opposition politicians, former Umno leaders and anti-graft bodies to demand a thorough investigation into the fund leading into such audit instruction $(\mathrm{Ng}, 2015 \mathrm{~b})$.

But, pray tell, what exactly are the goals of the audit by the Auditor-General? And, was the Auditor-General Office the only entity that various parties were hoping to find the truth regarding the $1 \mathrm{MDB}$ ? What has forensic auditing got to do with these questions? But, there are other questions of course. All this and more are raised and discussed next.

\section{What are the objectives of the audit by the auditor-general?}

It was in late 2014 that the auditor-general Ambrin Buang had said that he saw "no reason" to audit 1 MDB because it had already been audited by prominent audit firms (Chie, 2014). He was quoted to have said: "Why are we not auditing 1MDB? My answer is that its accounts have already been audited by one of the 'big four'. So there is no reason why we should come in again." And, such remarks had led the Petaling Jaya Utara MP Tony Pua to react on the very next day in the following manner (Sharmilla, 2014):

We call upon Ambrin to seriously consider including 1MDB as one of the future audit projects for the National Audit Department, because it is the single largest debtor in the country outside of the Government. If $1 \mathrm{MDB}$ with more than RM42 billion of debt, for one reason or another, collapses like another controversial firm - Renong Bhd in the late 1990s, then the implication for the country's economy will be earth-shattering.

This particular remark by Pua had failed to induce response from the auditor general. However, in late February 2015, the then head of PAC had this to say on why the audit by the auditor general was needed ("Number crunch 1MDB", 2015): "PAC wants the national audit department to carry out its audit on $1 \mathrm{MDB}$ first before we (PAC) call them to face us soon. The people need to know the truth and the government must be transparent about 1MDB. If all the investments and operations are legitimate then let it should be verified by a public 
entity, that is the Audit Department." He was also reported to have also said that the audit was necessary because $1 \mathrm{MDB}$ is entirely public owned and negative speculations about the firm will hurt the government.

Note that in the same news report, the then PAC head was said to have mentioned that the audit was supposed to look into the source of the RM2 billion recently used to settle the firm's debts. Other matters to audit were the reported government's injection of new funds amounting to RM3 billion, the deal with PetroSaudi and the contradicting statements on whether the monies in Cayman Islands had been brought back to Malaysia or not. Finally, the change in international auditing firms to approve 1MDB's account must also be looked into.

About a week later following these remarks coming from the then PAC head, the Parliamentarians Rafizi Ramli from Parti Keadilan Rakyat (PKR) and Tony Pua from the DAP had raised a number of matters that the audit by the AG needed to look into. When it concerns the former, he raised the matter of Terms of Reference (TOR) for the Auditor-General's audit of 1MDB. As far as Rafizi was concerned, the TOR (Fernandez, 2015a).

... must help establish every sen handled by $1 \mathrm{MDB}$ i.e. where monies were invested, how much was spent, and who the final beneficiaries were; whether every investment decision was based on good governance and in line with value in the market; that every investment brought in returns which justified the level of debts that 1MDB has to shoulder; establish the financial risks posed by $1 \mathrm{MDB}$ to the financial and banking system, the bond market and the economy; and identify individuals who may have been involved in wrongdoings and bring them to justice.

Finally, due to his fear that that the Auditor-General would be used "... to whitewash 1MDB as he was required to do in the case of NFC", Rafizi believed that it was crucial that the TOR be presented to Parliament for debate. Alas, no such thing has ever happened to this day. At any rate, on the very same day that Rafizi mentioned the TOR, his counterpart Tony Pua from the DAP was reported to have detailed out the areas which the AG needed to look into ("DAP hits out at Najib", 2015):

1) Auditing and identifying the redemption trail of the investments in Cayman Islands and the whereabouts of its proceeds. In particular, the Auditor-General should trace the money trail of the latest US\$1.103 billion redemption in January from Cayman Islands to the overseas bank account of $1 \mathrm{MDB}$ where the cash is supposedly parked. This is because $1 \mathrm{MDB}$ has to date refused to repatriate these funds back to Malaysia where it nearly defaulted on an RM2 billion loan.

2) Auditing and identifying the exact investment holding, true value and whereabouts of RM13.39 billion of "level-3 assets" identified in the March 2014 financial report. The figure includes the RM7.71 billion of investment in Cayman Islands which was declared as "redeemed". "Level-3 assets" are where "fair value measurements are those derived from valuation techniques that include inputs for the asset or liability that are not based on observable market data (unobservable inputs)." 
3) Confirming if $1 \mathrm{MDB}$ had to stoop to borrowing RM2 billion from local tycoon Tan Sri Ananda Krishnan to repay its debt and determine 1MDB's cashflow shortage to meet its RM42 billion debt obligations as well as contract commitments which are likely to require government bailout. This is especially pertinent given the failure of 1MDB's external auditors to red flag the risk of insolvency when they signed off on the latest financial report on November 5, 2014.

4) Confirming if all historical emails in the 1MDB mail server were "wiped out" in December last year, as said by Sarawak Report.

It is notable that in the same news report, Pua had urged the A-G to promptly begin an investigation into $1 \mathrm{MDB}$ and deliver a report to the PAC within 15 days.

Limited audit scope? Khairie Hisyam of Kinibiz which is associated with the news portal Malaysiakini had made it quite clear what was the problem with the AGO audit of 1MDB in a well written piece published in the middle of March 2015 (Khairie, 2015):

After years of criticism on dodgy dealings by controversial 1Malaysia Development Bhd (1MDB), a formal probe is now underway as Auditor-General Ambrin Buang began verifying the company's accounts last week. However there exists a glaring mismatch between the scope of the Auditor-General's probe and the myriad concerns raised over the years on $1 \mathrm{MDB}$, especially given more recent revelations that cast a starkly negative light on its dealings... The revelations and the controversy arising frame an issue that far extends beyond 1MDB's accounts, in turn posing the question of whether the Auditor-General's audit will be able to clear 1MDB's reputation. And the answer, it seems, is no. According to the statement issued by the Prime Minister's Office, the instruction by the prime minister for the Auditor-General to probe $1 \mathrm{MDB}$ is limited to the company's accounts. The Auditor-General's report on the matter would then be passed to the Public Accounts Committee for transparent inspection.

At the end of his writing, he also had this to say:

... the underlying implication of the prime minister's directive is that the Auditor-General's investigations will be strictly limited to what information is available in 1MDB's FY14 accounts. On the contrary, the more pressing issues raised by Sarawak Report revelations pertain to a number of financial years ago - during which 1MDB's auditor was a different firm - and goes beyond what is captured by financial accounts alone.

Next, he mentioned two of "the more pressing issues":

For one, did Jho Low indeed take a more active role in 1MDB's dealings than his often-repeated claims of merely offering advice to $1 \mathrm{MDB}$ as and when requested to do so? Another question is why $1 \mathrm{MDB}$ engaged in a joint venture with Petrosaudi in the first place, especially given the breakneck speed of events that unfolded since the joint venture unit, $1 \mathrm{MDB}$ Petrosaudi, was incorporated and why the latter was immediately saddled with debt to its parent upon incorporation. 
None other than forensic audit! It is notable that within the next few days after the prime minister had instructed the AGO to conduct audit on the $1 \mathrm{MDB}$, several notable personalities in the country had made the suggestion that it was none other than the forensic audit that should be conducted on the company. In fact, in the case of Tony Pua and the journalist P. Gunasegaram, they made the related remarks on the very next day after the prime minister had given his instruction to the AGO on $1 \mathrm{MDB}$ audit. As Pua was quoted to have said ("DAP hits out at Najib", 2015):

The A-G should conduct a forensic audit of $1 \mathrm{MDB}$ with the assistance of professional forensic auditors to uncover any financial shenanigans in the company, particularly in the light of the exposé by the Sarawak Report and the mind-boggling PetroSaudi transactions from 2009 to 2012. We look forward to working closely with the Auditor-General to ensure that any culprits who abetted or caused $1 \mathrm{MDB}$ to suffer from multi-billion ringgit losses will be prosecuted in court and punished for their treacherous conduct.

As for P. Gunasegaram, the founding editor of business news and views portal KiniBiz that is associated with the news portal the Malaysiakini, he had mentioned in his article the following (Gunasegaram, 2015a): "The right thing to do will be not to simply wait for the verification process by the auditor-general but to expand the scope into a full-blown, urgent, forensic audit to uncover wrongdoing. Only that can clear 1MDB... Indeed, much of what is wrong at $1 \mathrm{MDB}$ is not just at the accounting level of things."

And, at the end of the short but quite interesting piece that had a list of ten questions which he claimed Kinibiz had asked 1MDB for two long years to answer but to no avail, he mentioned what appeared to be some of the most disappointing transactions undertaken by the company to the detriment of the nation - but to the advantage of what appear to be the unscrupulous few:

Good account keeping - if indeed that is good at 1MDB - does not necessarily indicate that there are no wrongdoings. If you price your bonds wrongly for instance, nothing will show up as wrong in your accounts. But you would have squandered billions of ringgit of public money through the higher interest rates that 1MDB has to pay, sometimes for as long as 30 years. Smart people don't misprice by mistake, they usually do so for gain. There is considerable scope for wrongdoing here.Likewise for high fees paid, overpaying for assets, questionable use of assets and so on.

P. Gunasegaram ended his article by pointing out why normal audit was inadequate and why the forensic audit was the way to go. He wrote:

The kind of investigation required for $1 \mathrm{MDB}$ is different and not an auditor's report which examines books and expresses that all is fair and well with account keeping. What is required is a forensic audit of $1 \mathrm{MDB}$ which is aimed at uncovering all kinds of wrongdoing at $1 \mathrm{MDB}$, determining the money flows, the points at which corruption can occur, the people involved, and bringing them to book. If the auditor-general is simply going to do a normal audit, he is not going to discover much - it will be pretty much an echo of the Deloitte report. 
Within a few days after Pua and P. Gunasegaram claimed that it was the forensic audit which needed to take place as far as the $1 \mathrm{MDB}$ was concerned, the then deputy prime minister Tan Sri Muhyiddin Mohd Yassin, the former premier Tun Dr. Mahathir Mohamad and the former New Straits Times group editor-in-chief A. Kadir Jasin had also suggested the same. Interestingly, even after more than a couple of months after the prime minister had instructed the AGO to audit the $1 \mathrm{MDB}$, the blogger Syed Akbar Ali had also made it very clear that it was the forensic audit which needed to take place.

In the case of the then DPM, his remark on forensic audit came out in a 16 line statement published by the news portal The Malaysian Insider on March 6, 2015 - mere two days after the cabinet meeting on March 4, 2015 whereupon the prime minister gave out the instruction to the auditor general to conduct audit on the 1MDB (Muhyiddin, 2015). He specifically mentioned on the $9^{\text {th }}$ line of the 16 line statement: "Audit forensic hendaklah dilaksanakan untuk menentukan tiada penyelewengan kewangan berlaku dalam urusniaga 1MDB." (Forensic auditing has to be conducted to determine that there is no financial embezzlement taking place in the $1 \mathrm{MDB}$ transactions.)

Note that prior to that particular remark of his, he had among others mentioned that the audit scope of the auditor general should start from the very beginning of the company. This was because several cases of embezzlements alleged to have taken place were concerned with transactions that took place since 2009 and were not part of the 2013 accounting period that was audited by Deloitte. Next, he referred in particular to the joint venture between the 1MDB and PetroSaudi International which he said had been raised by a number of news portals. And, it is perhaps worth noting that he had pointed out that the auditor general must be given support in terms of resources and that the comprehensive audit report issued at the end of the process shall not take too long to be completed!

When it concerns the former New Straits Times group editor-in-chief A. Kadir Jasin, he fully supported the remark above from the then deputy prime minister (A-Kadir, 2015). In his blog piece that was dated the day after the then deputy prime minister made the remark, he mentioned: "Alhamdulillah, itulah kaedah yang tepat. Isu 1MDB memerlukan "forensic auditing" macam doktor menyiasat sejarah pesakit atau membedah mayat. Terima kasih Muhyiddin..." (Thanks to God - that is the right approach. The 1MDB issue needs "forensic auditing" similar to the manner taken up by a doctor in investigating a patient's history or in doing a post mortem on a dead body.")

Later on in the same blog piece, he came out with the following revealing remark: "Umumnya, pengkritik dan penganalisis bukan sekadar mempertikaikan akaun 1MDB. Mereka juga mengkritik dan menganalisis perkara-perkara yang tidak dijelaskan dalam laporan dan akaunnya - mungkin atas alasan rahsia perniagaan." (By and large, the critics and analysts of what is happening are not merely in doubt over the 1MDB's accounts. They are also criticizing and analyzing things which are not made clear in reports and the company's accounts - which could probably have taken place for the reason of business confidentiality.) Next, he narrated a rather long list of question marks over the company's actions over the years. These included a large amount of debts (over RM40 billion), assets 
bought at amount over the market price, capital outflow invested at the Cayman Islands, difficulty in paying back to local banks, the alleged involvement of billionaire $\mathrm{T}$ Ananda Krishnan in paying the company's debts, government link investment corporations being force to lend money to the company through the act of buying its bonds or sukuk and the involvement of mysterious parties such as Jho Low and PetroSaudi.

It is notable that right after saying all this, A. Kadir Jasin mentioned: "Kalau tugas Ketua Juruaudit Negara sekadar "verify" (mengesahkan) akaun IMDB, ia tidak lebih daripada "rubber stamp". Tetapi sekiranya KJN diberi kuasa khas atau beliau sendiri berani mengambil inisiatif melakukan "forensic auditing" barulah ada harapan kita menjejaki "money trail" untuk mengetahui siapa buat apa dan dapat apa." (If the task of the auditor general is merely to verify the $1 \mathrm{MDB}$ accounts, it is nothing more than a rubber stamp. On the other hand, there is hope in checking out the money trail to know who did what and who got what once the auditor general is bestowed with special power or that he himself is taking the initiative to conduct the forensic auditing.") It is perhaps worth noting that he had also mentioned the following in the very last paragraph of the blog piece: “... masalah 1MDB kalau tidak dibongkar dan diatasi boleh mencetuskan wabak sistemik yang sangat buruk ke atas ekonomi, fiskal, perbankan dan mata wang negara." (... the failure to uncover the problems faced by the $1 \mathrm{MDB}$ and to have these dealt with appropriately could lead to an extremely terrible systemic effect on the nation's economy, fiscal, banking system and currency.)

As for the former premier Tun Dr. Mahathir Mohamad, he claimed that a financial audit on the 1MDB's books was not sufficient and the police need to come in to conduct the forensic audit. He had this to say in his blog posting (Mahathir, 2015):

Kerajaan sudah melantik ketua audit negara untuk memeriksa akaun 1MDB. Tetapi ini tidak akan menjawab banyak soalan yang dikemukakan dan dibincang rakyat... Yang diperlukan bukan audit biasa buku akaun. Yang diperlukan ialah siasatan forensik oleh polis akan tuduhan yang dibuat terhadap beberapa orang yang terlibat dengan pengurusan wang $1 \mathrm{MDB}$. (The government has appointed the auditor general to audit the 1MDB's accounts. But this shall not be able to answer the various questions which the rakyat has raised and discussed... What is needed is not the normal audit which examines the accounting records. What is needed is a forensic investigation by the police over accusations made against several people who are involved in managing the 1MDB's finances.)

Finally, about two weeks after the prime minister instructing the auditor general to audit the $1 \mathrm{MDB}$, it should be worth pointing out a fine piece of writing by a person who come under the name of A.H. Manaf who took the trouble in detailing out the various facets of the forensic audit that need to take place as far as the probe of the AGO on 1MDB was concerned (A.-H.-Manaf, 2015). After having laying out the case of the $1 \mathrm{MDB}$ as a company in financial distress and which was followed right after with the conclusion that the company in 2015 without the financial support from the government was no longer a going concern, he had this to say:

In my previous article, I analysed publicly available information which signals "alarm 
bells" or "red flags" suggesting the possibility of irregular or fraudulent activities indicated by $1 \mathrm{MDB}$ 's frequent changes in external auditors, multiple and inexplicable late filings, unusual revaluation policy which served to mask its balance sheet insolvency, as well as the mysterious circumstances of the origins of the notorious US $\$ 2.3$ billion Caymans funds.

Next, he applauded the instruction made to the auditor-general to conduct a public audit of $1 \mathrm{MDB}$ - and which he noted as "... an engagement I had called for more than four months ago." Interestingly, he had that remarks of his followed with what so many others appeared to have failed to notice: "Notwithstanding the possible conflict of interest arising from the instruction given by the prime minister who is also the finance minister and chairman of 1MDB's advisory board, I welcome this move of a public audit and hope the AG will undertake his heavy responsibilities with independence and credibility." Also, in his own words, he pointed a number of things which such instruction should be inclusive of:

Critically the task requires a forensic audit (a specialised branch of audit which plays a crucial role in investigating suspected financial fraud and misappropriation of assets) with assistance from external specialist forensics if necessary. For a methodical approach demonstrating credibility to the public, deadlines and timeframes should be established, as well as clear terms of reference for the audit which should be made publicly available.

And, the reason for such details? As he put it: "These are crucial to allay public fears about the efficacy and intent of the public audit." As for the terms of reference (TOR) for the audit of the auditor general on the 1MDB in particular, he had them listed out with the opening remark that they"... should include but not be confined..." to the following four items:

- determine adherence to principles of corporate governance by $1 \mathrm{MDB}$ 's board and management;

- assess all evidence to determine any incidences of corporate malfeasance;

- determine the authenticity and validity of a number of 1MDB's controversial transactions and the extent of potential prejudice the company may have suffered through such transactions. This includes the joint venture with Petrosaudi; portfolio investment in offshore Caymans funds; the bond issue via Goldman Sachs; the option agreement with Aabar and compensation thereof relating to the proposed IPO; the joint venture with Aabar undertaken by 1MDB's former subsidiary SRC involving RM4 billion EPF funds, including investigating the reasons for and circumstances surrounding the transfer of the company's ownership to the MOF; and,

- quantify the magnitude and timing of $1 \mathrm{MDBs}$ current obligations and likely restructuring and financing cost.

Following the listing of these four items, A.H. Manaf had among others touched on the parties who the auditor general need to interview. As he put it:

The interviewees should include current and previous management, current and previous members of the board of directors and advisory board, current and previous external 
auditors, any other persons including external advisors and associates who may be directly involved in the company's transactions under investigation and any other persons who may be directly implicated by corporate malfeasance and fraudulent activities.

Finally, within the last few paragraphs of his brilliant write up, A.H. Manaf had mentioned the following: "In view of the international nature of the company's transactions and flow of funds and assets, the AG needs to assess the possibility of early referrals to criminal authorities to facilitate cross-borders investigations. Assistance from and cooperation with PDRM, its overseas counterparts, Bank Negara and other relevant authorities will be essential."

But approximately two months later - more remarks on auditor general to conduct none other than the forensic audit! At around two months after the auditor general was supposed to have conducted the audit on $1 \mathrm{MDB}$, one may find three prominent parties had again raised the matter of audit done by the auditor general on the 1MDB should be none other than the forensic type. The first came from the former chief minister of the state of Selangor who was also once one of the vice presidents of Umno Tan Sri Muhammad Muhd Taib (Md.-Izwan \& Hasbullah, 2015). In an exclusive interview that he gave to the news portal The Malaysian Insider, he was quoted to say:

Saya fikir bukan hanya pengauditan, tapi pengauditan forensik dan perakaunan perlu dijalankan, ia bagi mengetahui daripada segi pembelian tersebut, dikatakan ada yang terlampau mahal, ada yang dikatakan terlampau murah, mengapa jadi begini, IPP (jana kuasa bebas) itu mahal-mahal belaka, kata Dr. Mahathir. Ada juga beli tanah murah, beli tanah Sungai Besi dengan murah, bermakna rakyat rugi lah, pasal ini tanah rakyat. (I think it is not just any kind of auditing - but the forensic auditing and accounting which need to take place. This is to find out the truth behind the different buying transactions some were said to have taken place at exorbitant prices while others at dirt cheap prices. Why when it concerns the IPPs they were bought at exorbitant prices as said by Dr. Mahathir. And lands such as the one at Sungai Besi were bought at dirt cheap prices leading to the rakyat incurring losses since these were the rakyat's lands.)

Another person who raised the matter of forensic audit was the founding editor of business news and views portal KiniBiz P. Gunasegaram noted earlier. In a piece published at the end of April, he stressed the need for the $1 \mathrm{MDB}$ to answer a set of ten questions. As he put it early on (Gunasegaram, 2015b): "Considering that $1 \mathrm{MDB}$ continues to assert that everything is okay it really should not take too much for it to allay public concerns over how it started, raised money, invested, its links to various businessmen, etc. But in case it is stuck for what to disclose, we give below a checklist of 10 things, which will be good place to start." The following provides a sample of four out of the ten things that he argued needing disclosures from the 1MDB:

- Explain why such high fees of several hundred million US dollars was paid to Goldman Sachs for bonds floated and what was the nature of their role in such deals. While normal rates for arranging such financing is closer to 1 percent, why the need to pay 10 percent for these? 


\section{Macrothink}

- Was there hanky panky in the fundraising process whereby bonds were mispriced, allowing those who got the bonds to cash out in the secondary market to gain billions of ringgit? Was this the reason why the debts were ramped up repeatedly? If not explain why the bonds were mispriced and who were the beneficiaries, in other words who got first bite at the bonds.

- With RM42 billion of borrowings and an average interest rate of 6 percent, annual interest payments before repayments amounts to over RM2.5 billion. Considering that 1MDB has been making cash losses since inception, explain how 1MDB proposes to obtain the interest payments and repayments in future especially since energy assets are now worth below cost.

- Explain to us what is the oversight of the board and senior management over all these issues, especially in the light of Sarawak Report disclosures - which have not been firmly denied - that outside parties played crucial roles in decision-making.

And, at the end of the piece, P. Gunasegaram mentioned the need for the 1MDB to give answers to his list of ten items - immediately! That was in case the 1MDB was able to provide the full and satisfactory explanations to each of the ten items needing disclosures. Reasons? "...to allay the sizeable public concern and speculation, which has affected the value of the ringgit and our sovereign rating. At the same time it will relieve the considerable pressure on the prime minister to step down." But, in case the 1MDB was not capable to give the satisfactory answer to even one of these items, he claimed "... then it is incumbent upon the board of $1 \mathrm{MDB}$ and the government to immediately commission a forensic audit, put the organisation under a completely new caretaker management comprising people of impeccable character and get to the bottom of the entire issue." Next, he had the piece concluded with the following remark: "The forensic audit will have a mandate to not only recover fully all assets but to hold to account all those responsible for wrong-doings inside and outside the company and bring them to book. It will also look into taking action against all financial advisers and claim damages from them for anything that they may have done to injure 1MDB."

Finally, the last but certainly not the least, the blogger Syed Akbar Ali mentioned in May 2015 the following (Syed-Akbar-Ali, 2015):

... there seems to be some confusion over this 'audit' that everyone is looking forward to. Of course the crooks are also preparing the ground to confuse the public. Everyone is talking about 'the audit', the 'Auditor General's Report' etc. The PM has even tried to spin the 'audit' thingy by saying that 'two international auditors have already done their audits'. Implying what more can the Auditor General come up with? I think we have to watch the Auditor General very closely. Please don't do just another 'audit' and then confirm to everyone what the two international audit firms have also 'confirmed'. That will not be fair. That will not be honest. We need a forensic audit.

And, in the last few lines of his piece, he mentioned succinctly: "So Mr Auditor General, we want a Forensic Audit. Has the Auditor General performed forensic audits before? Most certainly. Please do not say you do not know how to perform a forensic audit. So to all 
Bloggers, Media people, anyone who is interested - the key phrase is Forensic Audit."

\section{Why declaring no wrongdoing at the same time wanting AGO audit?}

Following an early March 2015 briefing made to the federal cabinet by the top management of the 1MDB and its auditor Deloitte, the federal cabinet issued a statement that the cabinet was confident that there was no wrongdoing committed within the 1MDB (Gabriel, 2015). Nonetheless, on the very same day of making that statement, the prime minister had given an instruction to the AGO to audit 1MDB. Such mind boggling series of events had led Pua to come out with the following damning view ("DAP hits out at Najib", 2015):

This half-past six Cabinet must think Malaysians are complete fools, for how can 1MDB be cleared before even the Auditor-General starts his investigations? How can the Cabinet listen to $1 \mathrm{MDB}$ and its external auditors for less than 2 hours, without listening to any other parties, and immediately accept all the explanations without question? After all, if 1MDB was managed so well, why has the company accumulated more than RM42 billion in debt and had to beg local tycoon Tan Sri Ananda Krishnan for an RM2 billion emergency loan? Subsequently, 1MDB had to further appeal for another RM3 billion bailout by Putrajaya.

Pua was also reported to say that the "half-past six" ministers might not have understood the "complex" financial misappropriations that took place in 1MDB but that it did not give them the right to clear the company of any wrongdoing. He was quoted to say: "In fact, if the Cabinet had even bothered to read and understand the documents and emails exposed by Sarawak Report, they would have realised that 1MDB may have been stupid, but they were fully complicit in the various shenanigans that took place resulting in massive losses for the company."

Pua was certainly not alone in thinking that it was too early for the federal cabinet to say that the $1 \mathrm{MDB}$ had done no wrong. Note the following coming P. Gunasegaram mentioned earlier (Gunasegaram, 2015a):

There are very primary things which are wrong with self-styled strategic development company 1Malaysia Development Bhd or $1 \mathrm{MDB}$. Thus it is rather premature for the Cabinet to conclude that there has been no wrongdoing, which is what a statement from the Prime Minister's Office says. This is especially so after the prime minister announced that the auditor-general has been instructed to independently verify 1MDB's accounts.

\section{Why the failure to specify the necessary?}

Perhaps the main item of lacking is concerned with the lack of the terms of reference for the AGO audit as mentioned in a witty piece published in the Malaysia Today (Umar-Mukhtar, 2015): "Asking the Auditor-General to investigate without known Terms of Reference for the Rakyat to monitor progress and direction of investigations is lame governance." As for other lackings, note the following mentioned in a news report ("Broaden 1MDB audit", 2015):

Auditor-General Tan Sri Ambrin Buang had on March 10 reportedly said that the audit on debt-laden $1 \mathrm{MDB}$ has started with the gathering of relevant information. He said the 
auditing process would not only be confined to the accounts of 1MDB but also include the assets, liabilities, corporate governance and equities... However, no time frame was set or any mention made if the audit would go as far back as the company's TIA year.

Later in early May 2015, when Malaysians were confronted with the news that the Pilgrimage Fund's deposits were being used to purchase government land given to 1MDB at an inflated price and there was the great fear by many that 1MDB's mess could be seeping through to other important institutions such as the Employees Provident Fund and Pemodalan Nasional Bhd, the PKR MP Rafizi mentioned that the Auditor-General needed to complete its audit on the 1MDB (Anand, 2015). Why? As he was quoted to have said:

Without a formal certification of $1 \mathrm{MDB}$ 's problem, with a complete diagnosis of its lack of governance, it is difficult to expect the managements of these state institutions with great public interest to stand up and oppose instructions. They need something to fall back to when they are penalised for defending public interest. Hence, this is why it is of utmost urgency that the audit by the auditor-general cannot be delayed, not a single minute more.

But, there was just one problem as mentioned next in the very same news report: Rafizi “. .. is dismayed that the auditor-general has not even outlined the expectation of when this would be completed." Hence, he surmised, the instruction coming from the prime minister for the auditor-general to probe $1 \mathrm{MDB}$ now runs the risk of being seen as a mere announcement, meant to pacify public anger then, hoping it would go away. There could also be another reason for no authority figure had ever mentioned any dateline for the AGO's probe to be completed. Note the following coming from Pua in late April 2014 ("Stop lying and protecting", 2015): "Despite being forced to instruct the Auditor-General to 'verify' the $1 \mathrm{MDB}$ accounts signed off by Deloitte Malaysia, it would appear that it was merely a tactic to buy time as no deadline has been set for the investigations to be completed."

Finally, when there is the failure to specify the necessary such as the TOR and how long the probe was to take place, it would not be surprising that some skeptical minds would come to the inevitable conclusions on the real reason behind the AOG's probe. Note the following coming from the Parti Islam Se Malaysia (PAS) parliamentarian Mahfuz Omar just around a week after the prime minister had given instruction to the auditor-general to audit 1MDB (Malaysiakini, 2015): "I'm worried the audit will only be done to comply with a directive, to issue a 'halal' certificate so that all the financial mismanagement, swindling, abuse of power and breach of trust committed by 1 MDB will disappear."

It is also probably worth noting that Mahfuz had not only questioned the auditor-general's sincerity in auditing debt-ridden $1 \mathrm{MDB}$, but he had also raised the matter of the auditor-general's credibility to audit 1MDB. In regard to the latter, he was quoted: "I question the auditor-generals credibility, because the audit done by the auditor-general's office regarding the management of the National Youth Day celebrations 2011 and 2013 till now has not been tabled in Parliament." Finally, in the same news report, he was said to have filed a motion to establish a royal commission of inquiry to probe the state-owned investment arm. However, his motion was rejected by the Dewan Rakyat speaker, as an audit has already been 
ordered.

\section{Should the auditor-general be the one to audit the IMDB?}

In the previous section, it was mentioned that the parliamentarian Mahfuz had asked for a royal commission of inquiry to probe the $1 \mathrm{MDB}$. The truth is that Mahfuz was not alone in saying that there was a need for an entity other than the auditor-general to probe on the $1 \mathrm{MDB}$, for there were others who said the same thing just a few days later. They included none other than the former premier Tun Dr. Mahathir himself and a couple of journalists from Kinibiz.

When it concerns the former, it was barely a week after the auditor general Ambrin mentioning that the AGO audit on the 1MDB had began that Tun Mahathir Mohamad was reported to have called "... for a proper auditing by independent external parties into the $1 \mathrm{MDB}$ issue, which can dig deeper than an Auditor-General probe ("Dr. Mahathir: If people not with me", 2015). Tun was also quoted to have said: "They (the Auditor-General) audit the books but they don't do investigative reporting. What we need is a commission of inquiry made up of people who have no personal interest." But, he did not agree that there should be instead investigation in the form of a Royal Commission of Inquiry. Why? As he was quoted to say: "Not a royal commission; a royal commission is (full of) cowards. Even (when) I was called in before, it is a way for them (the government) to put me on the stand, but that's alright." Next, he suggested the need for what he called to be "neutral people" to do "a comprehensive scrutiny of $1 \mathrm{MDB}$ ". As he put it: "We need to have neutral people to do a thorough investigation on where the money went, who is handling the money, and who is this Jho Low. Why is he so important? Suddenly, he becomes so important when he has no position in the government or civil service but he has so much of power."

It is notable that on the very same day that Tun said all that, in the Kinibiz, the journalists Stephanie Jacob and Khairie Hisyam wrote (Jacob \& Khairie, 2015):

The time has come for Prime Minister Najib Abdul Razak to either set up a joint taskforce to investigate the entire $1 \mathrm{MDB}$ issue or to set up a Royal Commission of Inquiry to do the same. Now this is neither a question of the AG's ability or integrity; rather it has to do with the scope of what he will be investigating. It is a matter of what seems to be a glaring mismatch between the scope of the Auditor-General's probe and the myriad concerns raised over the years on $1 \mathrm{MDB}$, especially recent revelations that cast a starkly negative light on its dealings.

And, "the myriad concerns" as they put it included:

The pressing need for such an in depth investigation has been there for over two years since reports began emerging of how there may have been wrongdoing at $1 \mathrm{MDB}$. The trove of documents which Sarawak Report has been releasing over the past weeks further raises more questions especially as to who was really running $1 \mathrm{MDB}$. No matter what the motivation driving the release of the documents and pages of email correspondence is, the material itself cannot go unanswered... Assuming it is all authentic then there can no longer be limited investigations. A more substantive investigation must be undertaken, 
one that extends back to the genesis of the fund in September 2009 when the Terengganu Investment Authority became 1MDB.

Next, they stressed that every single deal and investment decision must be scrutinized from the very moment the TIA was formed. There was a need too to interview various parties who possessed high level decision making authority in 1MDB such as directors, chief financial officers and chief investment officers. They specifically named the former CEOs Shahrol Halmi and Mohd Hazem and both the former and current chairmen of 1MDB, Mohd Bakke Salleh and Lodin Wok Kamaruddin. Finally, they pointed out that outside consultants must be interviewed. In this regard, they mentioned the person known as Jho Low.

Within the last few paragraphs of their article, they mentioned that an in depth investigation was needed because the controversy over $1 \mathrm{MDB}$ was rapidly becoming bigger than just being about its financials. As they put it:

As multiple reports have emerged from the local press and foreign outlets like the New York Times linking Jho Low, 1MDB and the prime minister and implicating all three in questionable behaviour - the controversy has ballooned from being over an investment fund to dragging in a key Malaysian institution. Implications aimed at tainting the prime minister by extension taints his office, especially when there are suggestions of abuse of power on improper conduct. The prime minister then must take action to not just clear his name but to protect the dignity and integrity of his office. The best and only way to do this is a full and comprehensive review of $1 \mathrm{MDB}$. If the investigations are done half-heartedly, it will be painfully obvious and it will further erode the people's confidence in Malaysia's regulatory institutions.

In their very interesting piece of writing, the two journalists from Kinibiz had the following as their last few words:

There is no better time then now to end the controversy and intrigue surrounding 1MDB by appointing a Royal Commission of Inquiry with full powers to investigate, recommend prosecutions where necessary and detail measures to get restitution for losses.

All in all, Mahfuz, Tun Mahathir and the two journalists from the Kinibiz have pointed toward the need for a commission of inquiry (which may or may not be of the royal kind) and not the auditor general to probe the 1MDB. Aside from a commission of inquiry, another idea bandied around was to have an international audit firm to do the probing. Several personalities from the political party United Malays National Organisation (UMNO) which constitute one of the political parties forming the federal government had voiced such. There were the former premier Tun Mahathir, the former leader of an UMNO division Datuk Seri Khairuddin Abu Hassan and an UMNO vice president Datuk Seri Hishammuddin Hussein. It is notable that when it concerns Khairuddin he was among the first in UMNO to show grave concern on the goings on in $1 \mathrm{MDB}$ to the point of filing report with the police months prior to the prime minister instructing the AGO to audit the 1MDB.

An international audit firm to probe the 1MDB. In the case of Tun Mahathir he had argued 
for such some weeks prior to the prime minister instructing the AGO to audit the 1MDB. As noted The Malaysian Insider during the first half of February 2015, the former premier had given a speech during a forum in Kuala Lumpur (Zachariah, 2015). He mentioned, among others, that he would not have set up 1Malaysia Development Berhad (1MDB), the debt-heavy state investment vehicle, if he was still leading the nation. He was also quoted to say:

We should not have $1 \mathrm{MDB}$ at all. It is not a national wealth fund. We have to borrow money for it. How can you be rich if you borrow money? If you borrow some money from a chettiar (money lender), would you count yourself rich after receiving the money? No, you are poor. You are now indebted to the bank. So if you have excess money, then by all means have $1 \mathrm{MDB}$. But if you ask me, I would not have 1MDB if I were still the PM.

Subsequently, at a press conference, he had mentioned that the 1MDB should be investigated by independent auditors. As he put it: "This is now a controversy. It must be clarified. So one of the ways... is to have an independent audit of the company."

Following this remark from Tun Mahathir, approximately a month later which was just a couple of days after the prime minister had instructed the AGO to audit the 1MDB, the former Umno division leader Datuk Seri Khairuddin Abu Hassan argued for the presence of an international audit firm to audit the 1MDB's financial statements (Khairil, 2015). He had made this suggestion because he felt that it was too early for the federal cabinet to say that it had the confidence that there was no wrongdoing taking place in 1MDB after merely listening to the presentation given by the $1 \mathrm{MDB}$ and its auditor Deloitte.

Finally, later, in May 2015, approximately two months after the auditor-general Ambrin had pointed out that the probe on the 1MDB had started, Hishammuddin Hussein, one of the governing party vice-presidents who also happens to hold the post of defense minister at the federal cabinet, was reported in the newspaper Malay Mail Online to say that auditor-general needed to quickly prepare its report and present it to the PAC ("After TRX land row", 2015). Once that had taken place, he said, the 1MDB needed to undergo independent forensic audit on all transactions since inception. In another news report filed by the news portal The Malaysian Insider, he was also quoted to say the following ("Get international auditors", 2015):

To preserve the reputation of this investment firm and answer the public's questions, I suggest that the $1 \mathrm{MDB}$ board of directors appoint another international firm that is independent to examine, verify and reveal to the public all its assets, liabilities as well as the status of its investment portfolio and cash flow. This auditing firm must also carry out a forensic audit on all of 1MDB's transactions since its formation, to help 1MDB answer all the issues raised. 1MDB has become a hot issue that Malaysians are now focusing on. Hence, in my view, the government should answer the questions raised to remove negative perceptions surrounding this investment firm. 
Apparently, Hishammuddin made this remark for he shared the concerns raised by many on the recent selling of a piece of land in the Tun Razak Exchange (TRX) by the 1MDB to Lembaga Tabung Haji (LTH) (which is a savings fund for Muslim pilgrims to perform the haj in Mecca): the latter had paid a whopping RM188.5 million for 1.56 acres of the 70 -acre TRX land which 1MDB had purchased four years ago from the government of Malaysia for just RM4.5 million. In two consecutive paragraphs, the earlier mentioned Malay Mail Online report had made clear why many parties were concerned about the sale:

A blog called "The Benchmark" first drew attention to the purchase when it published purported documents of the controversial transaction that critics now claim could be a bailout for $1 \mathrm{MDB}$.

A confirmation by LTH on the purchase has since prompted bipartisan calls from lawmakers and private groups for the pilgrim funds board to explain the "high-risk" land buy from debt-laden $1 \mathrm{MDB}$, which is currently under probe by the Auditor-General's Department and Parliament's PAC.

Hence, in the above mentioned report published by the news portal The Malaysian Insider, Hishammuddin was said to have pointed out that the pilgrim fund, as a well-respected institution, should ensure all its deals are above board and that its integrity is protected. Next, he was quoted to say ("Get international auditors", 2015):

I am confident, the board members of the Lembaga Tabung Haji took into account the business risks and are working to ensure that the interests of its contributors are protected at all times. However, we must immediately get rid of this negative perception and suspicions among the market and society that the sale of the 1MDB land was a result of the financial burdens that the investment firm is facing.

It is notable that on the very same day those remarks by Hishammuddin were reported on by the media, the news portal The Malaysian Insider had come out with remarks supporting the minister (The Malaysian Insider, 2015a). Note the following:

As the 1Malaysia Development Bhd (1MDB) saga unfolds with many twists and turns, it is time for this elephant in the room to be tackled head on... The time for denials, promises of no cover up, inaction and slow action (in the case of the auditor-general) is over. And the best way forward is, as suggested by Umno vice-president and Defence Minister Datuk Seri Hishamuddin Hussein, to appoint an independent international auditor to do a thorough forensic audit of $1 \mathrm{MDB}$ from its inception. We support Hishamuddin's call and we propose that PricewaterhouseCoopers $(\mathrm{PwC})$ - as the only firm among the big four which has not handled the $1 \mathrm{MDB}$ account - be appointed to do it.

As for what PwC was supposed to do in its forensic audit, the news portal had them pointed out:

PwC should be asked to come out with a true picture of the assets and liabilities of $1 \mathrm{MDB}$ within a month. And a thorough forensic audit covering all the deals starting with 
the first RM5 billlon bond issue and the aborted joint venture with Petrosaudi International, right down to the newest transactions must be done within three months. Last but not least, a forensic audit must also look deep into the role of Malaysian businessman Low Taek Jho (better known as Jho Low) and his dealings with top 1MDB executives, in particular its former chief executive Datuk Shahrol Halmi. What must also be looked into is whether the board of directors from the time Tan Sri Mohd Bakke Salleh was chairman to his successor Tan Sri Lodin Wok Kamaruddin had failed in their duty to ensure proper governance.

Note that the news portal had also made what appeared to be a crucial final suggestion in this regard: "In order to ensure that $\mathrm{PwC}$ has absolute freedom to do the forensic audit, we propose that the government set up an independent team that will work with $\mathrm{PwC}$ to get to the bottom of the matter. No one from 1MDB or its owner, the Ministry of Finance, should be involved. And PwC reports only to this independent team."

From the above discussion of questions raised on the AGO audit on the 1MDB, one may be safe to conclude that surely the government had attempted to answer some if not all of them. Well, the truth is that there were some answers provided - but there is a good chance that these would not easily satisfy anyone. You shall be the judge... In fact, there were some remarks made by those on the government side which seem to lead to more confusion. Again, you can judge for yourself... See next.

\section{Some answers you say...?}

Within a few days after Rafizi and Pua had gone to the media to announce what they believed to be the various tasks which the AGO need to focus on its probe of the 1MDB, the auditor-general himself had gone to the media to spell out his tasks (Md-Izwan, 2015). He was quoted to have said: "The focus is on the accounts. We'll look at all accounts, previous accounts included. Anything related to asset and liability, we have to study. We want to know how the company is being managed." On getting outside helps, he had this to say: "We will do whatever is necessary in this audit even if we have to bring outside parties (experts) to investigate, after all we've done it before. So this is quite normal."

Later on at the end of March 2015 after the brouhaha coming from Rafizi and Mahfuz (mentioned earlier) that the AGO audit on the $1 \mathrm{MDB}$ was not serious and merely to pacify the public who clamor for truth on the latter's affairs, there was an attempt made to urge the public not to be suspicious. Noted minister Paul Low Seng Kuan (Bernama, 2015a):

The government is serious in getting to the truth. The Auditor-General is requested to do the audit not just about the account but whatever that is necessary to get to the truth, particularly areas relating to what the public is worried about. There are some people who claimed that this is a classic way of distracting comments by the public but it is not true. The Auditor-General's findings will be presented to the Public Accounts Committee (PAC) which is bipartisan, transparent and open.

It is also notable that in that very same news report there was the mentioning that a special task force comprising representatives from the Attorney-General's Chambers and the 
Malaysian Anti-Corruption Commission (MACC) had been formed to investigate into complaints on the status of the 1MDB. Next, it mentioned that the minister Low had said that the audit by the Auditor-General and the task force were carried out simultaneously and independently. He was also quoted to have said: "Please bear in mind that they are not receiving instructions from anyone and (there is) no interference too. I can assure you that it is proceeding independently to verify accusations because the public need to know (the truth). The Auditor-General's report will be made public."

In any of those statements coming from either the auditor-general or the minister, not even once the term forensic audit was mentioned. And yet the Barisan Nasional Backbenchers Club (BNBBC) chairperson Shahrir Abdul Samad had this to say in reference to what he said to be the investigations conducted by the PAC and the auditor general and which was reported by the government's national news agency Bernama (Bernama, 2015b): "The forensic audit being conducted by the authorities will make it difficult for 1MDB to protect its business activities. Any dubious measure will be questioned by NAD and PAC, which have the authority to question anyone on the company's (1MDB) affairs since its establishment in 2009."

Note this was mentioned around two weeks after the prime minister on March 4 directed the auditor-general to audit the $1 \mathrm{MDB}$. If that was not strange enough, in the news portal Free Malaysia Today, the following was mentioned as coming from none other than the prime minister himself within a few days after he instructed the 1MDB audit by the AGO (FMT Reporter, 2015b): "Najib, briefing Umno division chiefs at a party gathering today, had reiterated his stand that the company's accounts had undergone a forensic audit by Deloitte Malaysia, who had cleared 1MDB officials."

Also, on the very same day that the remark by Najib above was reported, note that the news portal Free Malaysia Today had published remarks made by the then minister in charge of among others a body that collects companies' annual reports (FMT Reporter, 2015c). Early on, the minister claimed that the Companies Commission of Malaysia (CCM) had analyzed the deposited financial statements of the 1MDB from 2010-2014 that were given the clean audit reports by the auditors. He was quoted to say: "Sehingga hari ini, tiada pelaporan oleh juruaudit 1MDB kepada SSM di bawah Seksyen 174 (8A) Akta Syarikat berhubung kesalahan serius seperti 'penipuan dan penyelewengan' ditemui sewaktu proses audit dijalankan terhadap 1MDB." (Until today, there is no report made by the auditor of 1MDB to CCM under Section 174 (8A) of the Companies Act in relation to any finding of serious violations such as 'fraud and embezzlements' while conducting the audit process.) Hence, he concluded that the misappropriation of funds in $1 \mathrm{MDB}$ was merely an accusation and had been denied by the relevant parties such as the 1MDB and Petro Saudi Limited.

Finally, note that in the middle of April 2015, just over a month after the AGO was supposed to have started its probe in the $1 \mathrm{MDB}$, the head of the PAC who previously had said that the PAC would wait for the A-G to complete checks on 1MDB's books before launching its own probe had now mentioned that that might not be the case after all ("Panel may start 1MDB", 2015). He claimed that it was not the intention of the committee to pressure the A-G to speed 
up its audit. Instead, the PAC's sole intention to conduct its own separate probe was to dispel any talk the government was trying to hide something should there be a delay in the AGO's probe. After all, in his view, the AGO's probe might take some time to be completed since it involved looking at some foreign transactions that the company had gone into.

And so in early May 2015 it was reported that the PAC will start questioning those linked with 1MDB when Parliament resumes its session (The Malaysian Insider, 2015b). The first group to be questioned was comprised of the ministry of finance officials who were involved in the setting up of the company. They will be followed by 1MDB executives, the company board and the auditors. Interestingly, the same news report had disclosed that the hearing would be a continuation of the one which took place in 2012 under the then PAC chairman Tan Sri Azmi Khalid.

Note that the earlier hearing had made the conclusion that the company had a healthy balanced sheet. This was based on one single document out of a total of seven documents requested from the company. That one single document available online was comprised of the company's financial statements for March 2011. The other six documents requested but which the then PAC had failed to receive from the company were related to 1MDB's investments with PetroSaudi International Limited.

All in all, there are several important questions which the authorities have failed to give satisfactory answers to - as far as the audit done by the auditor general to the 1MDB is concerned. This is quite unfortunate for Malaysians who are hoping that that audit could amount to some clarity - and justice for the country. Now, as far as you are concerned, do you agree with the questions raised above? What do you think of the few and seemingly unsatisfactory answers coming from the authorities? Why do you think the Malaysian authorities have failed to provide the good and satisfactory answers? What is the way out for Malaysia and Malaysians who want clarity and justice as far as the 1MDB is concerned? How do you think the audit done by the $1 \mathrm{MDB}$ will end up with? And, finally, what do you make of the following quotation (Fernandez, 2015b):

Malaysia's past, degenerating from a Federation into a unitary state where the premiership has virtually become a dictatorship, has caught up with it in the present to haunt its future. It's a recipe for disaster and that's what happened: the 1Malaysia Development Berhad (1MDB) is a national disaster of epic proportions. One person presided over the Ministry of Finance-owned $1 \mathrm{MDB}$, touted as a strategic investment company. The bottomline is that not much hope can be placed on the audit that Prime Minister and Finance Minister Najib Abdul Razak has ordered on 1MDB. The consensus is that it's the normal response of a government seeking to drag out things into inaction and hoping that ultimately everything would be forgotten and that it can be business as usual. 


\section{Macrothink}

Journal of Public Administration and Governance

ISSN 2161-7104

2016, Vol. 6, No. 1

\section{References}

After TRX land row, Umno veep says international auditors should vet 1MDB's books (2015, May 9). Malay Mail Online. Retrieved from http://www.themalaymailonline.com/malaysia/article/after-trx-land-row-umno-veep-says-inte rnational-auditors-should-vet-1mdbs-b

A-Kadir, J. (2015, March 7). Audit Forensik 1MDB -Terima Kasih Muhyiddin. The Malaysian Insider. Retrieved from http://kadirjasin.blogspot.my/2015/03/audit-forensik-1mdb-terima-kasih.html

Anand, R.K. (2015, May 8). Rafizi: Mr Auditor, where's the 1MDB report? Malaysiakini. Retrieved from https://www.malaysiakini.com/news/297686

Aw, N. (2015, March 5). Did KPMG help 1MDB in PetroSaudi cover-up? Malaysiakini. Retrieved from http://www.malaysiakini.com/news/291026

Bernama (2015a, March 26). Gov't serious about the truth on 1MDB, says Paul Low. Kinibiz. Retrieved from http://www.kinibiz.com/story/corporate/156576/govt-serious-about-the-truth-on-1mdb-says-p aul-low.html?utm_source=applet_mkinicom\&utm_medium=web\&utm_campaign=mkinicom Bernama (2015b, March 17). Any irregularities in 1MDB will be traced, vows Shahrir. Kinibiz. $\quad$ Retrieved from http://www.kinibiz.com/story/corporate/154157/any-irregularities-in-1mdb-will-be-traced-vo ws-shahrir.html?utm_source=applet_mkinicom\&utm_medium=web\&utm_campaign=mkinic om

Broaden 1MDB audit, says veteran newsman (2015, March 15). The Malaysian Insider. Retrieved from http://www.themalaysianinsider.com/malaysia/article/broaden-1mdb-audit-says-veteran-news man

Chie, K.G. (2014, November 12). Auditor-general says no reason to audit 1MDB. Malaysiakini. Retrieved from https://www.malaysiakini.com/news/280266

DAP hits out at Najib after Cabinet clears 1MDB of wrongdoing (2015, March 5). The Malaysian Insider. Retrieved from http://www.themalaysianinsider.com/malaysia/article/dap-hits-out-at-najib-after-cabinet-clear s-1mdb-of-wrongdoing

Dr M: If people not with me, why go on TV? (2015, April 26). Malaysiakini. Retrieved from https://www.malaysiakini.com/news/295512

Fernandez, J. (2015a, March 5). Rafizi: Don't whitewash 1MDB audit. Free Malaysia Today. Retrieved from http://www.freemalaysiatoday.com/category/nation/2015/03/05/1mdb-no-more-whitewashesrafizi-warns/ 


\section{Ml Macrothink}

Journal of Public Administration and Governance

ISSN 2161-7104

2016, Vol. 6, No. 1

Fernandez, J. (2015b, March 16). Najib's audit of 1MDB scandal a no-hoper. Free Malaysia Today. Retrieved

from

http://www.freemalaysiatoday.com/category/nation/2015/03/16/najibs-audit-of-1mdb-scandal -a-no-hoper/

FMT Reporters (2015a, April 14). PAC 'in a hurry’ to audit 1MDB. Free Malaysia Today. Retrieved from http://www.freemalaysiatoday.com/category/nation/2015/04/14/pac-in-a-hurry-to-audit-1mdb /

FMT Reporter (2015b, March 8). Najib promises no cover for 1MDB fraud. Free Malaysia Today. Retrieved

from http://www.freemalaysiatoday.com/category/nation/2015/03/08/najib-promises-no-cover-for$1 \mathrm{mdb}-$ fraud/

FMT Reporter (2015c, March 8). Audit kewangan 1MDB Bersih. Free Malaysia Today. Retrieved from http://www.freemalaysiatoday.com/category/bahasa/2015/03/08/audit-kewangan-1mdb-bersih /

Get international auditors to do forensic check on 1MDB, says Hishammuddin (2015, May 9). The Malaysian Insider. Retrieved from http://www.themalaysianinsider.com/malaysia/article/get-international-auditors-to-do-forensi c-check-on-1mdb-says-hishammuddin

Gunasegaram, P. (2015a, March 5). Too early to clear RM50 bil 1MDB of wrongdoing. Kinibiz. Retrieved from http://www.kinibiz.com/story/tigertalk/150994/too-early-to-clear-rm50-bil-1mdb-of-wrongdo ing.html?utm_source=applet_mkinicom\&utm_medium=web\&utm_campaign=mkinicom

Gunasegaram, P. (2015b, April 29). 10 things 1MDB should disclose. Malaysiakini. Retrieved from https://www.malaysiakini.com/columns/296794

Jacob, S. \& Khairie, H. (2015, March 20). Why 1MDB needs a royal probe. Kinibiz. Retrieved from http://www.kinibiz.com/story/issues/154960/why-1mdb-needs-a-royal-probe.html?utm_sourc e=applet_mkinicom\&utm_medium=web\&utm_campaign=mkinicom

Khairie, H. (2015, March 17). Is AG probe on 1MDB accounts enough?_Kinibiz. Retrieved from

http://www.kinibiz.com/story/issues/154068/is-ag-probe-on-1mdb-accounts-enough.html?ut m_source=applet_mkinicom\&utm_medium=web\&utm_campaign=mkinicom

Khairil, A. (2015, March 6). 1MDB : Khairuddin cadang juruaudit antarabangsa bebas kaji 1MDB. Free Malaysia Today. Retrieved from http://www.freemalaysiatoday.com/category/bahasa/2015/03/06/1mdb-khairuddin-cadang-jur uaudit-antarabangsa-bebas-kaji-1mdb/ 


\section{Macrothink}

Journal of Public Administration and Governance

ISSN 2161-7104

2016, Vol. 6, No. 1

Mahathir, M. (2015, March 13). 1MDB - Dr Mahathir Mohamad. The Malaysian Insider.

Retrieved

from

http://www.themalaysianinsider.com/rencana/article/rakyat-berhak-rasa-curiga-dr-mahathir-m ohamad

Malaysiakini (2015, March 12). 'Auditor-general only wants to declare 1MDB halal'. Kinibiz.

Retrieved

from

http://www.kinibiz.com/story/corporate/153130/auditor-general-only-wants-to-declare-1mdbhalal.html

Md-Izwan (2015, March 10). 1MDB audit will cover all accounts, says Auditor-General. The Malaysian Insider.

Retrieved

from

http://www.themalaysianinsider.com/malaysia/article/1mdb-audit-will-cover-all-accounts-say s-auditor-general

Md-Izwan \& Habullah, A.-C. (2015, April 27). Malaysia bankrap jika Umno abai amaran Dr $\mathrm{M}$ tentang $1 \mathrm{MDB}$, kata bekas naib presiden. The Malaysian Insider. Retrieved from http://www.themalaysianinsider.com/bahasa/article/malaysia-bankrap-jika-umno-abai-amaran -dr-m-tentang-1mdb-kata-bekas-naib-pr

Muhyiddin, Y. (2015, March 6). Pengauditan 1MDB mesti telus dan bebas - Muhyiddin Yassin. The Malaysian Insider. Retrieved from http://www.themalaysianinsider.com/rencana/article/pengauditan-1mdb-mesti-telus-dan-beba s-muhyiddin-yassin

Ng, E. (2015a, March 5). Did KPMG cover up for 1MDB over PetroSaudi deal, asks DAP. The Malaysian Insider. Retrieved from http://www.themalaysianinsider.com/malaysia/article/did-kpmg-cover-up-for-1mdb-over-petr osaudi-deal-asks-dap

Number crunch 1MDB, PAC tells audit dept (2015, February 26). Malaysiakini. Retrieved from https://www.malaysiakini.com/news/290366

Panel may start 1MDB audit without A-G's findings, says report (2015, April 14). The Malaysian Insider. Retrieved from http://www.themalaysianinsider.com/malaysia/article/panel-may-start-1mdb-audit-without-ags-findings-says-report

Sharmilla, G. (2014, November 13). Pua disagrees with auditor-general over 1MDB. Kinibiz. Retrieved from http://cms-m.kinibiz.com/story/corporate/121004/pua-disagrees-with-auditor-general-over-1 mdb.html?login_error=?login_error=

Stop lying and protecting Jho Low, DAP tells Najib (2015, April 24). The Malaysian Insider. Retrieved from http://www.themalaysianinsider.com/malaysia/article/stop-lying-and-protecting-jho-low-dap-t ells-najib 


\section{Macrothink}

Journal of Public Administration and Governance ISSN 2161-7104 2016, Vol. 6, No. 1

Syed-Akbar-Ali (2015, May 19). It Should Be "Forensic Audit" Ok, Not Just Any Audit. Retrieved from http://syedsoutsidethebox.blogspot.com/2015/05/it-should-be-forensic-audit-ok-not-just.html The Malaysian Insider (2015a, May 9). Hishammuddin right about independent audit, PwC best for the job. The Malaysian Insider. Retrieved from http://www.themalaysianinsider.com/malaysia/article/hishammuddin-right-about-independent -audit-pwc-best-for-the-job

The Malaysian Insider (2015b, May 4). PAC to quiz those linked to 1MDB. The Malaysian Insider. from http://www.themalaysianinsider.com/malaysia/article/pac-to-quiz-those-linked-to-1mdb Umar-Mukhtar (2015, May 5). To save the PM or the Party. Malaysia Today. Retrieved from http://www.malaysia-today.net/to-save-the-pm-or-the-party/

Zachariah, E. (2015, February 12). No 1MDB if I were still PM, says Dr M. The Malaysian Insider. from http://www.themalaysianinsider.com/malaysia/article/no-1mdb-if-i-was-still-pm-says-dr-m 